\title{
TMR Properties for magnetic tunnel junctions with a disordered $\mathrm{Co}_{2}\left(\mathrm{Cr}_{1-x} \mathrm{Fe}_{x}\right) \mathrm{Al}$ electrode
}

\author{
S. Okamura*, A. Miyazaki", N. Tezuka ${ }^{*, * *}$, S. Sugimoto*, K. Inomata ${ }^{*, * *}$, Y.K. Takahashi ${ }^{* * * *}$, and K. Hono ${ }^{* * * *}$ \\ *Department of Materials Science, Faculty of Engineering, Tohoku University, Aobayama 6-6-02, Aoba-ku, Sendai 980-8579, Japan \\ ${ }^{* *}$ CREST-JST, 4-1-8 Honcho Kawaguchi, Saitama 332-0012, Japan \\ ${ }^{* * *}$ National Institute for Materials Science, 1-2-1 Sengen, Tsukuba 305-0047, Japan
}

Polycrystalline and single crystalline thin films of $\mathrm{Co}_{2}\left(\mathrm{Cr}_{1-x} \mathrm{Fe}_{x}\right) \mathrm{Al}\left(x_{x}=0.6,1\right)$ full-Heusler alloys with different disordering were prepared on thermally oxidized $\mathrm{Si}$ and $\mathrm{MgO}(001)$ substrates, respectively, by the dc magnetron sputtering method. The magnetic tunnel junctions with a polycrystalline and single crystalline $B 2$ type $\mathrm{Co}_{2} \mathrm{FeAl}\left(x_{x}=\right.$ 1) electrode demonstrate TMR of $70 \%$ and $75 \%$ at $5 \mathrm{~K}$, respectively, which is larger than that of $65 \%$ at $5 \mathrm{~K}$ for $\mathrm{Co}_{75} \mathrm{Fe}_{25}$, indicating that the spin polarization for $\mathrm{Co}_{2} \mathrm{FeAl}$ is larger than that for $\mathrm{Co}_{75} \mathrm{Fe}_{25}$. The TMR for $\mathrm{Co}_{2} \mathrm{FeAl}$ with both the $A 2$ and the $B 2$, which is controlled by substrate heating, is almost the same, whereas for $\mathrm{Co}_{2}\left(\mathrm{Cr}_{0.4} \mathrm{Fe}_{0.6}\right) \mathrm{Al}$ the TMR increases with increasing the degree of ordering, corresponding to the first-principles calculations.

Key words: magnetic tunnel junctions, full-Heusler alloys, half-metal, atomic site disorder, thin films

\section{不規則構造を有する $\mathrm{Co}_{2}\left(\mathrm{Cr}_{1 \cdot x} \mathrm{Fe}_{x}\right) \mathrm{Al}$ を用いた強磁性トンネル接合の TMR 特性

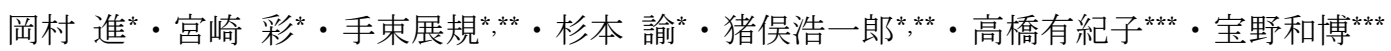 \\ *東北大学大学院工学研究科, 宮城県仙台市青葉区荒巻字青葉 6-6-02 (†980-8579) \\ ${ }^{* *}$ CREST-JST，埼玉県川口市本町 4-1-8（广980-8577） \\ ***物質・材料研究機構，茨城県つくば市千現 1-2-1( テ 305-0047)}

\section{1. はじめに}

近年，電子の電荷とスピンの両方を制御したスピントロニクス の分野において，ハーフメタルの研究が活発になってきた. ハー フメタルとは, フェルミ準位近傍において一方のスピン電子しか もたないバンド構造をもつ特殊な磁性材料であり, 強磁性トンネ 儿接合 (MTJ) や CPP-GMR 素子の磁気抵抗 (MR) 比の増大, あるいは半導体中へのスピン注入源材料として期待されている.

八ーフメタルとして理論的に報告される材料には大別して (1) 酸化物系 ( $\mathrm{La}_{0.7} \mathrm{Sr}_{0.3} \mathrm{MnO}_{3}{ }^{1}{ }^{2}, \mathrm{Fe}_{3} \mathrm{O}_{4}{ }^{2)}$ など)，（2）化合物半導体 $\left(\mathrm{CrAs}^{3}\right)$ など), (3) ホイスラー合金 $\left.\left(\mathrm{NiMnSb}^{4}\right), \mathrm{Co}_{2} \mathrm{MnSi}^{5}\right)$, $\mathrm{Co}_{2} \mathrm{CrAl}$ )など) が挙げられる. この中でも $\mathrm{La}_{0.7} \mathrm{Sr}_{0.3} \mathrm{MnO}_{3}(\mathrm{LSMO})$ を電極に持つMTJにおいて $5 \mathrm{~K}$ で 1800\%もの大きなトンネル磁 気抵抗（TMR）比が得られ7），ハーフメタルの肯定的な証拠（ス ピン分極率にして 95\%) となっている. しかし，LSMO を始めと するペロブスカイト系酸化物ではキュリー温度が低く，室温では 大きな TMR が得られていない. つまり, 室温で高いTMR を発現 させるためにはキュリー温度が室温よりも十分に高い材料の選択 が必要である．もう一つ材料選択の際に重要な点は，スピン分極 率の原子サイト不規則性に対する而性である. ホイスラー合金の 中でも $L 21$ 構造 $\left(\mathrm{X}_{2} \mathrm{YZ}\right)$ を有するフルホイスラー合金は, $\mathrm{Co}_{2}\left(\mathrm{Cr}_{1-x} \mathrm{Fe}_{x}\right) \mathrm{Al}$ でこれまで我々が報告してきたように8) 10), 高キュリー温度，不規則構造に対寸る而性の点からも有力な材料 である. 最近では, 理論的にも多くのフルホイスラー合金が $B 2$ 構 造のような不規則な状態においても高いスピン分極率を保つとい うことが報告されている11-12).

本論文では熱酸化膜付き $\mathrm{Si}$ および $\mathrm{MgO}(001)$ 単結晶基板上に作 製した $\mathrm{Co}_{2}\left(\mathrm{Cr}_{1-x} \mathrm{Fe}_{x}\right) \mathrm{Al}(x=0.6,1)$ フルホイスラー合金薄膜 の結晶構造を調べた結果に加え，その構造と TMR 特性との相関 について調べた結果を, 理論で報告されるスピン分極率と比較し
述べる.

\section{2. 実験方法}

$\mathrm{Co}_{2}\left(\mathrm{Cr}_{1 \cdot x} \mathrm{Fe}_{x}\right) \mathrm{Al}(x=0.6,1)$ 薄膜は化学量論組成合金ター ゲットを用いて, 超高真空マグネトロンスパッタ装置（到 達真空度 $2 \times 10^{-7} \mathrm{~Pa}$ ）で成膜された，基板には熱酸化膜付 き $\mathrm{Si}$ 基板と $\mathrm{MgO}(001)$ 基板を用いて，成膜中は規則化を促 すため室温〜 $773 \mathrm{~K}$ で基板加熱を行った. $\mathrm{MgO}$ 基板を用い る場合には成膜前に同チャンバー中で $873 \mathrm{~K}, 1$ 時間の熱 処理を施した。組成分析は ICP 発光分析, 試料の構造解析 にはXRDと TEM を用いた。 また, 表面モフォロジーの観 察には AFM を用いた。

MTJ は以下の構造で作製した. Sub./Co2 $\left(\mathrm{Cr}_{1-x} \mathrm{Fe}_{x}\right) \mathrm{Al}(20)$ $/ \mathrm{Al}(1.2)-\mathrm{O}_{x} / \mathrm{Co}_{75} \mathrm{Fe}_{25}(3) / \mathrm{Ir}_{22} \mathrm{Mn}{ }_{78}(10) / \mathrm{Ta}(\mathrm{cap})$ (単位 : nm). $\mathrm{Al}-\mathrm{O}_{\mathrm{x}}$ は $\mathrm{Al}$ の成膜後に 90〜 150 秒の ICP 酸化を施すこと で得られた. 成膜は大気暴露することなくin-situで作製し, その後, フォトリソグラフィーと Ar イオンミリングを用 いて $10 \times 10 \mu \mathrm{m}^{2}$ のサイズで素子を作製した。TMR は直流 4 端子法を用いて $5 \mathrm{~K}$ から室温の温度範囲で測定した。

\section{3. 実験結果}

\section{1 構造解析}

熱酸化膜付き $\mathrm{Si}$ 基板上に作製した $\mathrm{Co}_{2}\left(\mathrm{Cr}_{1 \cdot x} \mathrm{Fe}_{x}\right) \mathrm{Al}(100 \mathrm{~nm})$ はこれまで報告してきたように室温での成膜で $A 2$ 構造と なり, 加熱温度の増大とともに規則化が進行し $B 2$ 構造と なった ${ }^{13)}$. XRD の結果から $x=1$ の $\mathrm{Co}_{2} \mathrm{FeAl}$ では全温度領 域に渡って異なる結晶構造を持つ異相は析出しなかったが, $x=0.6$ の場合には $673 \mathrm{~K}$ 以上の加熱温度で hcp 構造を持 つ異相の析出が確認された. ICP 発光分析による組成分析 


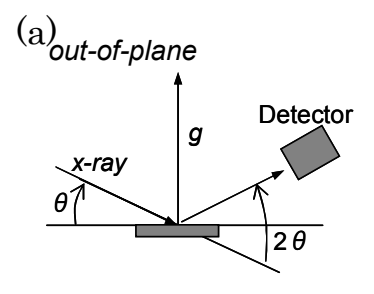

in-plane
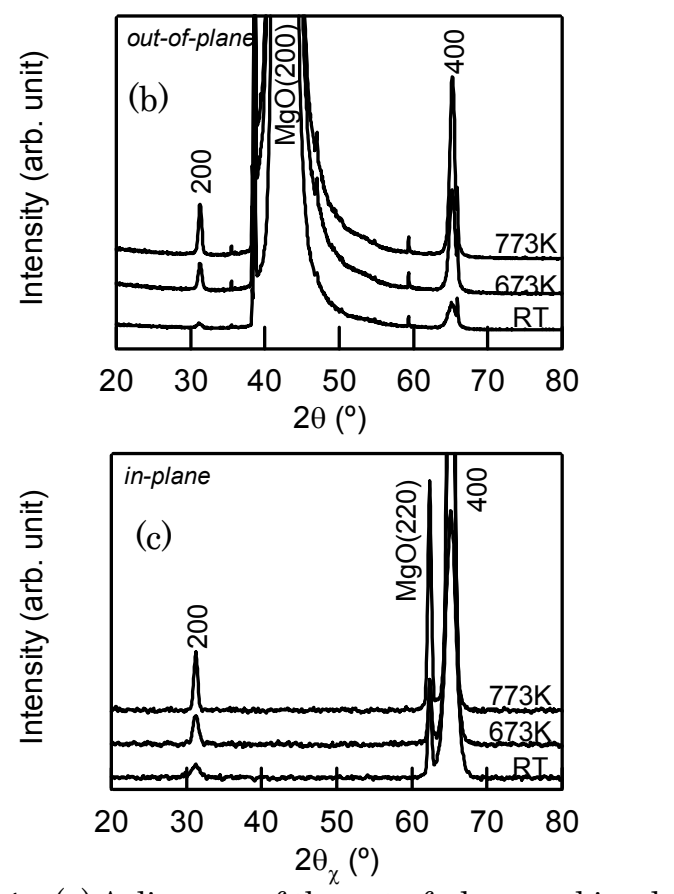

Fig. 1 (a) A diagram of the out-of-plane and in-plane XRD geometry. (b) Out-of-plane and (c) in-plane XRD patterns for $\mathrm{Co}_{2} \mathrm{FeAl}(20 \mathrm{~nm})$ on $\mathrm{MgO}(001)$ substrates. $\mathrm{Co}_{2} \mathrm{FeAl}$ films are deposited at RT, $673 \mathrm{~K}$, and $773 \mathrm{~K}$, respectively.

から各々の組成は $\mathrm{Co}_{2.09} \mathrm{Fe}_{1.00} \mathrm{Al}_{0.91}, \mathrm{Co}_{2.12} \mathrm{Cr}_{0.44} \mathrm{Fe}_{0.64} \mathrm{Al}_{0.81}$ と Co が過剰であったことから, 異相は hcp-Co の可能性が ある. 一方, $\mathrm{MgO}(001)$ 基板上に作製した場合，上記熱酸化 膜付き $\mathrm{Si}$ 基板とは異なる結果となった. Fig. 1 に $\mathrm{MgO}(001)$ 上に作製した $\mathrm{Co}_{2} \mathrm{FeAl}(20 \mathrm{~nm})$ の XRD パターン ((b) $\phi-2 \theta_{\chi}$, (c) $\theta$-20)を示す ((a)に配置図を示す)。ここで, in-plane 測 定は散乱べクトルを $\mathrm{MgO}$ の 110 方向に合わせた. out-of-plane 方向の測定は基板に垂直方向<001>が散乱べ クトルに対応する. in-plane, out-of-plane 両測定ともに薄 膜の 200，400 ピークだけが見られており，基板に対し面 内，面直方向ともに高配向に結晶成長していることがわか る.また RT での成膜でも 200 ピークが出現しており, 熱 酸化膜付き $\mathrm{Si}$ 基板を用いた結果と異なり， B2 構造へ規則 化していることが示唆される. 次に in-plane 測定で基本反

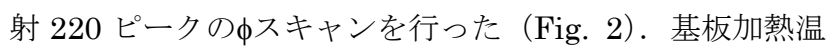
度の増大とともに半值幅が減少し, 室温成膜で $2.0^{\circ}$ であっ たが $773 \mathrm{~K}$ の成膜では 0.42 となった。これは薄膜の歪が 緩和したためと考えられる. $x=0.6$ の $\mathrm{Co}_{2}\left(\mathrm{Cr}_{0.4} \mathrm{Fe}_{0.6}\right) \mathrm{Al}$ に おいても同様の高配向結晶成長が見られた。前述したよう に，熱酸化膜付き $\mathrm{Si}$ 基板上に作製した場合，この組成では $673 \mathrm{~K}$ 以上の温度での基板加熱成膜で hcp-Co 相析出が見

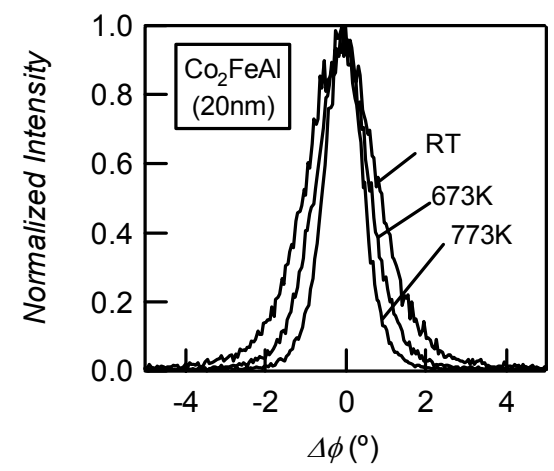

Fig. 2 X-ray in-plane rocking curves for $\mathrm{Co}_{2} \mathrm{FeAl}(20$ $\mathrm{nm}$ ) on $\mathrm{MgO}(001)$ substrates. $\mathrm{Co}_{2} \mathrm{FeAl}$ films are deposited at RT, $673 \mathrm{~K}$, and $773 \mathrm{~K}$, respectively.

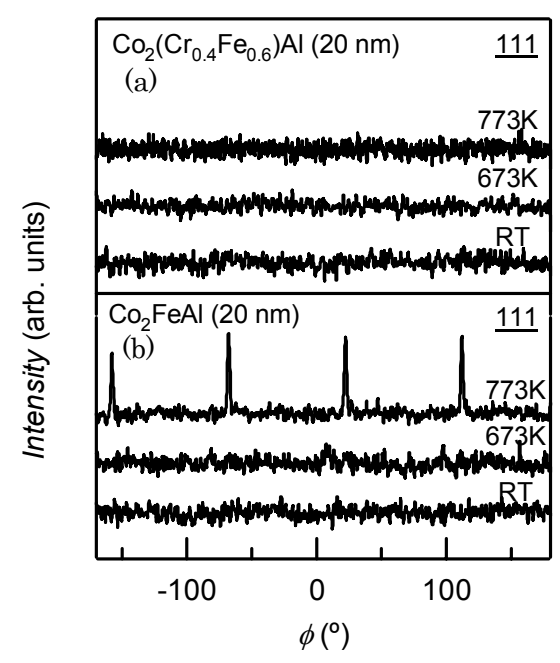

Fig. $3 \phi$ scan in 111 for (a) $\mathrm{Co}_{2}\left(\mathrm{Cr}_{0.4} \mathrm{Fe}_{0.6}\right) \mathrm{Al}(20 \mathrm{~nm})$ and (b) $\mathrm{Co}_{2} \mathrm{FeAl}(20 \mathrm{~nm})$ on $\mathrm{MgO}(001)$ substrates. $\mathrm{Co}_{2} \mathrm{FeAl}$ films are deposited at RT, $673 \mathrm{~K}$, and $773 \mathrm{~K}$, respectively.

られたが, $\mathrm{MgO}(001)$ 基板上に作製した場合，基板上のエピ タキシャル成長が異相の析出を抑制したためか, 異相の析 出が確認されなかった. TEM 観察においても同様に, $B 2$ 相以外の析出相はなく単相であることが確認された。

次に，L2 1 超格子ピークの観測を行うため, $2 \theta, 2 \theta_{\chi}$ 方向 を 111 方向に固定し, $\mathrm{Co}_{2}\left(\mathrm{Cr}_{1-x} \mathrm{Fe}_{x}\right) \mathrm{Al}$ の 111 ピークфスキ ヤン測定を行った (Fig.3). $x=0.6,1$ のどちらの組成に おいても RT, $673 \mathrm{~K}$ での成膜では $L 21$ 構造を示す 111 ピ 一クは観測されないが, $\mathrm{Co}_{2} \mathrm{FeAl}$ は $773 \mathrm{~K}$ での基板加熱で 4 回対称のピークが確認された. 220 ピークに対する 111 ピークの強度比はおよそ $0.6 \%$ 程度で, 計算值の $6 \%$ に比較 してかなり小さく, 完全な $L 22_{1}$ 構造ではないことが示唆さ れる. また, 面内、面直方向の格子定数は成膜温度に依存 せず、ともに $0.573( \pm 0.001) \mathrm{nm}$ となり、バルク值 $(0.573$ $\mathrm{nm})^{14)}$ に一致した. なお, $773 \mathrm{~K}$ で作製された $\mathrm{Co}_{2} \mathrm{FeAl}$ の $L 21_{1}$ 構造は膜断面の TEM 観察によっても確認された.この ように基板加熱温度の増大とともに規則度が増大している ことがわかる.これらの構造解析結果を纏めると Table 1 のようになる. 次にこれらの結晶構造を持つ $\mathrm{Co}_{2}\left(\mathrm{Cr}_{1-x} \mathrm{Fe}_{x}\right) \mathrm{Al}$ $(20 \mathrm{~nm})$ を下部電極にもつ MTJ の作製を行った. 
Table 1 The crystal structure for $\mathrm{Co}_{2}\left(\mathrm{Cr}_{1-x} \mathrm{Fe}_{x}\right) \mathrm{Al}(20$ $\mathrm{nm}$ ) films deposited on thermally oxidized $\mathrm{Si}$ and $\mathrm{MgO}(001)$ substrates. The crystal structures are characterized by XRD and TEM.

\begin{tabular}{|c|c|c|c|c|c|}
\hline Materials & $\mathrm{T}_{\mathrm{S}}(\mathrm{K})$ & $\mathrm{RT}$ & 573 & 673 & 773 \\
\hline \multirow{2}{*}{$\mathrm{Co}_{2} \mathrm{FeAl}$} & Oxi. Si & $\mathrm{A} 2$ & B2 & $\mathrm{B} 2$ & B2 \\
\hline & $\mathrm{MgO}(001)$ & $\mathrm{B} 2$ & $\mathrm{~B} 2$ & $\mathrm{~B} 2$ & $\mathrm{~L} 22_{1}$ \\
\hline \multirow{2}{*}{$\begin{array}{c}\mathrm{Co}_{2}\left(\mathrm{Cr}_{0.4} \mathrm{Fe}_{0.6}\right) \\
\mathrm{Al}\end{array}$} & Oxi. Si & $\mathrm{A} 2$ & $\mathrm{~B} 2$ & $\mathrm{~B} 2+\mathrm{Co}$ & $\mathrm{B} 2+\mathrm{Co}$ \\
\hline & $\mathrm{MgO}(001)$ & $\mathrm{B} 2$ & $\mathrm{~B} 2$ & $\mathrm{~B} 2$ & $\mathrm{~B} 2$ \\
\hline
\end{tabular}

\section{2 不規則 $\mathrm{Co}_{2}\left(\mathrm{Cr}_{1-x} \mathrm{Fe}_{x}\right) \mathrm{Al}$ を有するMTJ の作製}

下部磁性層にそれぞれ $\mathrm{Co}_{2} \mathrm{FeAl}, \mathrm{Co}_{2}\left(\mathrm{Cr}_{0.4} \mathrm{Fe} \mathrm{F}_{6}\right) \mathrm{Al} ， \mathrm{Co}_{5} \mathrm{Fe} 25$ ， 上部磁性層に $\mathrm{Co}_{75} \mathrm{Fe}_{25}$ を用いた MTJ の TMR の熱処理温度依存 性を Fig. 4 に示寸.ここでの熱処理とはMTJ 作製後に施す磁場中 熱処理（2 kOe）を指す. $\mathrm{Al}$ 絶縁層の設計膜厚は $1.2 \mathrm{~nm}$ (酸化前 の $\mathrm{Al}$ 膜厚), 酸化時間は $135 \mathrm{~s}$ と固定した. また, $\mathrm{Co}_{2}\left(\mathrm{Cr}_{1-x} \mathrm{Fe}_{x}\right) \mathrm{Al}$ 磁性層は全て室温で成膜した。全ての試料において熱処理 を施すことで MR 比が増大したが， $\mathrm{Co}_{75} \mathrm{Fe}_{25}$ を電極に用い た場合には $548 \mathrm{~K}$ で MR の最大值を取っているのに対し, $\mathrm{Co}_{2}\left(\mathrm{Cr}_{1{ }_{x} \mathrm{Fe}_{x}}\right) \mathrm{Al}$ を下部電極に用いた場合には比較的低い 473 498 K でピークを取り，その後 MR は減少した。一般 に, $\mathrm{CoFe}$ 電極を用いたもので熱処理により TMR が増大す るのは, 過酸化となった下部磁性層の酸素が $\mathrm{Al}$ 絶縁層に引 き寄せられるというモデルで説明される， $\mathrm{Co}_{2}\left(\mathrm{Cr}_{1-x} \mathrm{Fe}_{x}\right) \mathrm{Al}$ は酸素アフィニティの高い $\mathrm{Al}$ を含んでいるため, $498 \mathrm{~K}$ 以 上の熱処理で磁性層側へ酸素が移動し，MR の減少が早く 進行したのかもしれない。これを裏付ける実験として, 絶 縁層の障壁高さ, 幅の熱処理温度依存性を調べた。

Fig. 5 に熱酸化膜付き $\mathrm{Si}$ 基板上に作製した MTJ におけるバリ ア特性の熱処理温度依存性を示す。ここで，バリア特性は I-V 測 定から Simmon's fitting を用いて算出した. $\mathrm{Co}_{75} \mathrm{Fe}_{25}$ を用いた場 合，熱処理温度とともにバリア高さの増大，幅の減少が見られ， 所謂“シャーブなバリアになっていることがわかる，一方，

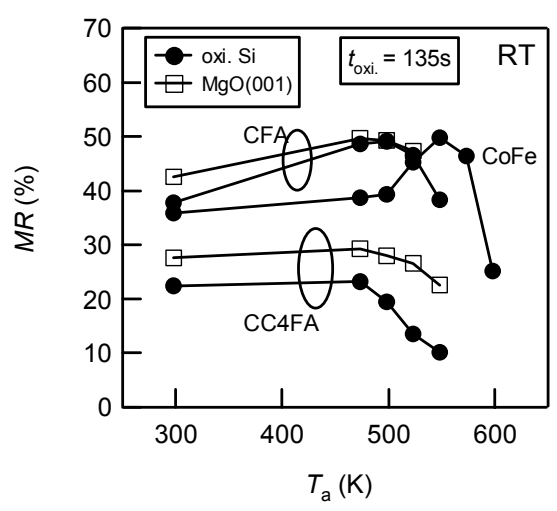

Fig. 4 Annealing temperature dependence of MR ratio for $\mathrm{Co}_{2}\left(\mathrm{Cr}_{1 \cdot{ }_{x}} \mathrm{Fe}_{x}\right) \mathrm{Al}\left(20 \mathrm{~nm}\right.$ ) (or $\mathrm{Co}_{75} \mathrm{Fe}_{25}$ )/ $\mathrm{Al}(1.2)-\mathrm{O}_{\mathrm{x}} / \mathrm{Co}_{75} \mathrm{Fe}_{25}(3) / \mathrm{IrMn}(10) / \mathrm{Ta}$ (cap). The bottom electrode is deposited at RT. The CFA, CC4FA, and $\mathrm{CoFe}$ indicate $\mathrm{CO}_{2} \mathrm{FeAl}, \mathrm{Co}_{2}\left(\mathrm{Cr}_{0.4} \mathrm{Fe}_{0.6}\right) \mathrm{Al}$, and $\mathrm{Co}_{55} \mathrm{Fe}_{25}$, respectively.

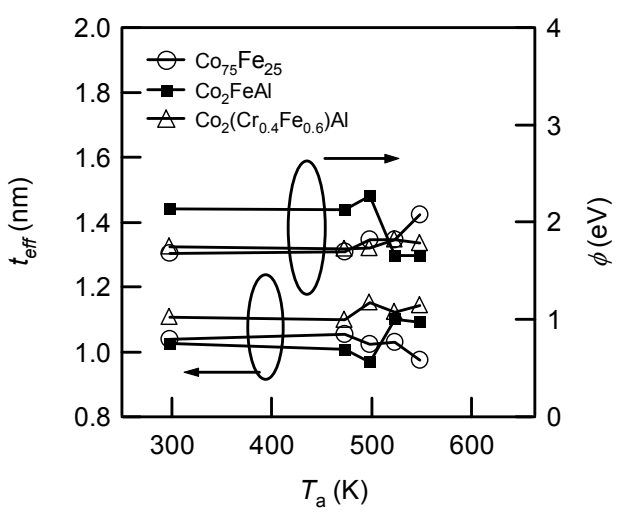

Fig. 5 Annealing temperature dependence of effective barrier thickness (left) and height (right) for $\mathrm{Co}_{2}\left(\mathrm{Cr}_{1 \cdot x} \mathrm{Fe}_{x}\right) \mathrm{Al}\left(20 \mathrm{~nm}\right.$ ) (or $\left.\mathrm{Co}_{75} \mathrm{Fe}_{25}\right) / \mathrm{Al}(1.2)-\mathrm{O}_{\mathrm{x}} /$ $\mathrm{Co}_{75} \mathrm{Fe}_{25}$ (3)/ IrMn(10)/ Ta(cap). The bottom electrode is deposited at RT.

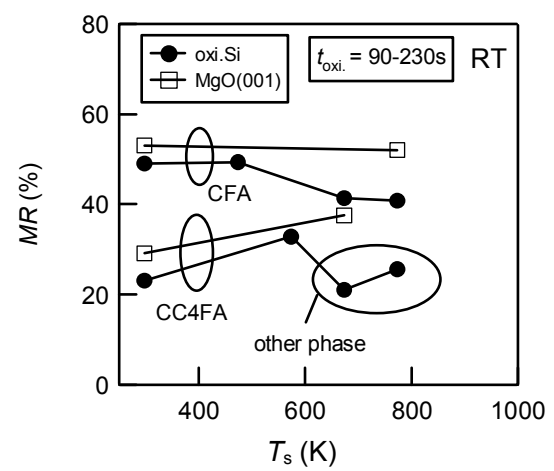

Fig. 6 Substrate temperature dependence of MR ratio for $\mathrm{Co}_{2}\left(\mathrm{Cr}_{1-x} \mathrm{Fe}_{x}\right) \mathrm{Al}(20 \mathrm{~nm})$ (or $\left.\mathrm{Co}_{75} \mathrm{Fe}_{25}\right) /$ $\mathrm{Al}(1.2)-\mathrm{O}_{\mathrm{x}} / \quad \mathrm{Co}_{75} \mathrm{Fe}_{25}(3) / \quad \operatorname{IrMn}(10) / \mathrm{Ta}(\mathrm{cap})$. The oxidation time is verified in the range of 90 to $230 \mathrm{~s}$. The CFA and CC4FA indicate $\mathrm{Co}_{2} \mathrm{FeAl}$ and $\mathrm{Co}_{2}\left(\mathrm{Cr}_{0.4} \mathrm{Fe}_{0.6}\right) \mathrm{Al}$, respectively.

$\mathrm{Co}_{2} \mathrm{FeAl}$ を電極に用いた場合，MR の最大值を取る $498 \mathrm{~K}$ を境に 急激にバリア特性が悪くなっていることがわかる.これは先に述 ベたように $\mathrm{Co}_{2} \mathrm{FeAl} の \mathrm{Al}$ 原子の酸化が原因と考えられる. 実際に XPS を用いて $\mathrm{Co}_{2} \mathrm{FeAl}$ 単相膜表面の化学結合状態を調べたところ, 表面において $\mathrm{Al}$ 原子が選択的に酸化しやすいことがわかった10),13). 次に結晶構造と MR の関係を調べた. 熱酸化膜付き $\mathrm{Si}$ 基板と $\mathrm{MgO}(001)$ 基板上に基板加熱作製した $\mathrm{Co}_{2}\left(\mathrm{Cr}_{1-x} \mathrm{Fe}_{x}\right) \mathrm{Al}$ を下部電 極にもつ MTJ の MR の結果を Fig. 6 に示す. 初めに $\mathrm{Co}_{2} \mathrm{FeAl}$ の結果を見ると, $\mathrm{MgO}(001)$ 基板上に作製した場合 には RT, $773 \mathrm{~K}$ での成膜でどちらもほぼ同じ TMR を示し ているのに対し, 熱酸化膜付き $\mathrm{Si}$ 基板上に作製した場合に は成膜温度を増大させると室温での TMR が 49\%から $42 \%$ へと若干減少した。一方, $\mathrm{Co}_{2}\left(\mathrm{Cr}_{0.4} \mathrm{Fe}_{0.6}\right) \mathrm{Al}$ を用いた場合, 異 相が析出した温度範井で TMR が大きく減少したが，それ以外で はどちらの基板を用いた場合でも基板加熱温度の増大と供に TMR が増大した. $\mathrm{Co}_{2}\left(\mathrm{Cr}_{0.4} \mathrm{Fe}_{0.6}\right) \mathrm{Al}$ では得られた最大の TMR は室温で $38 \%$ と理論どおりの大きな TMR は得られて いないが，これは完全な $B 2$ 構造ではなく $\mathrm{Co}-\mathrm{Cr}-\mathrm{Fe}$ 間で不 規則を伴った結晶構造となっているためと考えられる 9),11). 


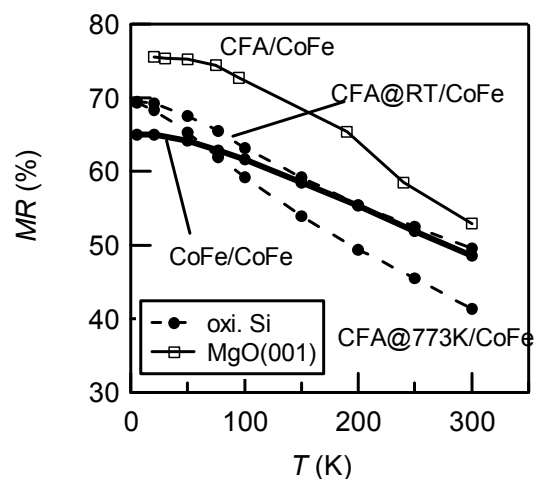

Fig. 7 Temperature dependence of $\mathrm{MR}$ ratio for $\mathrm{Co}_{2}\left(\mathrm{Cr}_{1-x} \mathrm{Fe}_{x}\right) \mathrm{Al}(20 \mathrm{~nm})$ (or $\left.\mathrm{Co}_{75} \mathrm{Fe}_{25}\right) / \mathrm{Al}(1.2)-\mathrm{O}_{\mathrm{x}} /$ $\mathrm{Co}_{75} \mathrm{Fe}_{25}(3) / \mathrm{IrMn}(10) / \mathrm{Ta}$ (cap). The CFA, CC4FA, and $\mathrm{CoFe}$ indicate $\mathrm{Co}_{2} \mathrm{FeAl}, \mathrm{Co}_{2}\left(\mathrm{Cr}_{0.4} \mathrm{Fe}_{0.6}\right) \mathrm{Al}, \quad$ and $\mathrm{Co}_{75} \mathrm{Fe}_{25}$, respectively.

次に TMR の温度変化を Fig. 7 に示す. $\mathrm{Co}_{2} \mathrm{FeAl}$ は $\mathrm{Co}_{75} \mathrm{Fe} 25$ を 用いた場合と室温でのTMRにほとんど違いが見られなかったが, $100 \mathrm{~K}$ 付近から TMR に徐々に差が現れ始め, $5 \mathrm{~K}$ では $\mathrm{Co} 2 \mathrm{FeAl}$ (A2)/Al-O/Co75Fe25 で 70\%が得られたのに対し, $\mathrm{Co}_{75} \mathrm{Fe} 25 / \mathrm{Al}-\mathrm{O} /$ $\mathrm{Co}_{75} \mathrm{Fe}_{25}$ では $65 \%$ となった. Jullière の式を用いて $\mathrm{Co}_{75} \mathrm{Fe}_{25}$ のス ピン分極率を算出すると 0.50 となり, 強磁生体絶縁体超伝導体 接合での報告值と同程度である15)ことがわかる．同様に $\mathrm{Co}_{2} \mathrm{FeAl}$ (A2) のスピン分極率は 0.52 となった. また， $B 2$ 構造の $\mathrm{Co}_{2} \mathrm{FeAl}$ を用いたMTJでも低温で $70 \%$ と $A 2$ 構造と同じTMRが得られた. 室温で TMR が低い原因は清浄な界面が得られていないためだと 考えられる. 基板加熱 $773 \mathrm{~K}$ で作製された $\mathrm{Co}_{2} \mathrm{FeAl}$ は $\mathrm{AFM}$ で測 定した結果, $R a=1.05 \mathrm{~nm}, P-V=8.1 \mathrm{~nm}$ と表面ラフネスが大 きく, 絶縁層を ICP 酸化した際に酸化しきれなかった絶縁層の $\mathrm{Al}$ や下部 $\mathrm{Co} 2 \mathrm{FeAl}$ の表面の酸化などが TMR の温度依存性を大きく した原因かもしれない，また，同グラフには $\mathrm{MgO}(001)$ 基板上の $\mathrm{Co}_{2} \mathrm{FeAl}$ を電極とした結果も描画されている. 室温で $\mathrm{MgO}(001)$ 基板上に成膜した $\mathrm{Co}_{2} \mathrm{FeAl}$ は規則度の低い $B 2$ 構造であったが, 5 $\mathrm{K}$ で $75 \%$ の TMR が得られており, スピン分極率にして 0.56 とな った. 理論的な $\mathrm{Co} 2 \mathrm{FeAl}$ のスピン分極率は $L 21, B 2, A 2$ 構造で それぞれ $0.85,0.61,0.62$ と報告されており 12), 16), 今回得られた 值は $B 2$ 構造で $0.56, A 2$ 構造で 0.52 であるから, どちらも理論 にかなり近い值が得られていることがわかる. また, 完全な L 21 構造が得られれば $140 \%$ を超えるTMR が得られることになる.

最近, $L 22_{1}$ 構造を有する $\mathrm{Co}_{2} \mathrm{MnSi}$ を用いた MTJ で $2 \mathrm{~K}$ で $160 \%$ と高い TMR が報告されているが17)， $\mathrm{Co}_{2} \mathrm{MnSi}$ の利点は低温で規 則化しやすく, 約 573 673 K の熱処理で $L 2_{1}$ 構造が得られること である. また, 不利な点は界面の Mn が酸化しやすく抵抗が大き くなってしまうことであろう。一方, $\mathrm{Co}_{2} \mathrm{FeAl}$ は $\mathrm{Al}$ が酸化しやす いにも関わらず接合抵抗が低いが，873 K までの熱処理では $L 21$ 構造が得られず, $773 \mathrm{~K}$ の基板加熱成膜でもわずかにしか規則化 しない. 最近, 我々が現在実験を進めている $\mathrm{Co}_{2} \mathrm{FeSi}$ は $\mathrm{Co}_{2} \mathrm{MnSi}$ と同様に低温熱処理においても $L 22_{1}$ 構造に規則化しやすいことが 分かってきた ${ }^{18)}$. 界面でのフルホイスラー合金薄膜の酸化を考え ると $\mathrm{Mn}$ や $\mathrm{Al}$ などが含まれていないことが望ましい. フルホイス ラ一合金 $\left(\mathrm{X}_{2} \mathrm{YZ}\right)$ において, Z 原子の置換はそれほじ電子構造に 影響を与えないことが理論的に予測されているため ${ }^{19)}, L 22_{1}$ 構造を
有する $\mathrm{Co}_{2} \mathrm{Fe}(\mathrm{Al}, \mathrm{Si})$ の作製など, 今後さらに研究を進めていく必 要がある.

\section{4. まとめ}

マグネトロンスパッタリング法により多結晶および単結晶 $\mathrm{Co}_{2}\left(\mathrm{Cr}_{1-x} \mathrm{Fe}_{x}\right) \mathrm{Al}$ 薄膜を作製し, その構造と TMR 特性を評価した. 作製条件を変化させることで種々の規則度を持つ $\mathrm{Co}_{2}\left(\mathrm{Cr}_{1-x} \mathrm{Fe}_{x}\right) \mathrm{Al}$ の作製に成功した. 多結晶 $\mathrm{Co}_{2} \mathrm{FeAl}$ では $A 2$ 構造, $B 2$ 構造で $5 \mathrm{~K}$ で 70\%と理論に近い TMR (RA = $\left.100 \mathrm{k} \Omega \mathrm{mm}^{2}\right)$ が得られ, また $\mathrm{MgO}(001)$ 基板上に作製した場合には室温で成膜した場合でも 5 $\mathrm{K}$ で $75 \%$ の TMR が得られた. 一方 $\mathrm{Co}_{2}\left(\mathrm{Cr}_{0.4} \mathrm{Fe}_{0.6}\right) \mathrm{Al}$ では規則 度の増大と供に TMR は単調に増大（最大で 38\%(室温)） した.このように, 規則度と TMRには密接な関係があり, 結晶構造をより精密に制御することで, 今後より大きな TMR が観測されると考えられる.

謝辞 本研究は文部科学省主要 5 分野の研究事業の IT プロ グラム, 基盤研究 A(15206074)ならびに科学研究費補助金特 定領域研究(14076202)により行われた.

\section{References}

1) E.A. Livesay, R.N. West, S.B. Dugdale, G. Santi, and T. Jarlborg: J. Phys. Condens. Matter 11, L279 (1999).

2) R.A. de Groot, and K.H.J. Buschow: J. Magn. Magn. Mater. 54, 1377 (1986).

3) H. Akinaga, T. Manago, and M. Shirai: Jpn. J. Appl. Phys., Part 2 39, L1118 (2000).

4) R.A. de Groot, F.M. Mueller, P.G. van Engen, and K.H.J. Buchow: Phys. Rev. Lett. 50, 2024 (1983).

5) S. Fujii, S. Sugimura, S. Ishida, and S. Asano: J. Phys.: Condens. Matter 2, 8583 (1990).

6) Y. Miura, K. Nagao, and M. Shirai: Phys. Rev. B 69, 144413 (2004).

7) M. Bowen, M. Bibes, A. Barthélémy, J.-P. Contour, A. Anane, Y. Lemaître, and A. Fert: Appl. Phys. Lett. 82, 233 (2003).

8) K. Inomata, S. Okamura, R. Goto, and N. Tezuka: Jpn. J. Appl. Phys., Part 2 42, L419 (2003).

9) S. Okamura, R. Goto, S. Sugimoto, N. Tezuka, and K. Inomata: J. Appl. Phys., 96, 6561 (2004).

10) S. Okamura, A. Miyazaki, S. Sugimoto, N. Tezuka, and K. Inomata: Appl. Phys. Lett. 86, 232503 (2005).

11) Y. Miura, K. Nagao, and M. Shirai: Phys. Rev. B 69, 144413 (2004).

12) Y. Miura, K. Nagao and M. Shirai: Collected Abstracts of the 2005 Spring Meeting of the Japan Society of Applied Physics and Related Societies (2005) pp. 544.

13) S. Okamura, A. Miyazaki, N. Tezuka and K. Inomata: IEEJ Trans. $F M$ (in press).

14) K. Kobayashi (private communication).

15) D.J. Monsma and S.S.P. Parkin: Appl. Phys. Lett. 77, 720 (2000).

16) M. Shirai (private communication).

17) Y. Sakuraba, J. Nakata, M. Oogane, H. Kubota, Y. Ando, A. Sakuma and T. Miyazaki: Jpn. J. Appl. Phys., Part 2 44, L1100 (2005).

18) M. Kikuchi, S. Okamura, T. Masaki, N. Tezuka, S. Sugimoto, K. Inomata: J.Magn.Soc.Jpn (submitted).

19) S. Ishida, S. Fujii, S. Mizutani, S. Asano: Materia Japan 44, 630 (2005).

2005年10月19日受理，2006年2月21日採録 